\title{
CHRISTELIKE GODSDIENS EN EIESOORTIGE
}

\section{VOLKSDIENS}

'n Beoordeling van die boek van Prof. Dr. A. B. Du Preez, Eiesoortige Ontwikkeling tot Volksdiens. H.A.U.M., Pretoria, 1959

Hierdie boek wat die ondertitel, Die Hoop van Suid-Afrika dra, het een doelstelling en 'n half-dosyn skywe. Die doelstelling is om met Bybelse en ander argumente rasse-apartheid in alle moontlike betrekkinge, die Kerk inkluis, te propageer. Soos uit die loop van die bespreking sal blyk, is die werk in wese 'n propaganda-skrif. Terwyl die doel 'n ideologie is, t.w. die al-oue apartheid onder die nuwe naam, eiesoortige ontwikkeling, laat die skrywer nie na om alle rersone en instellinge wat op een of ander tydstip in een of ander verband die politieke ideologie van apartheid gekritiseer het, te bestry nie . . . Prof. Keet dus, Prof. Ben Marais, die Werêldraad van Kerke, Amerika en sommer die hele Weste en nader tuis, die Engelse pers en sommer die Engelse in die algemeen.

Die skrywer be-oog volgens die Inleiding om ,deurgaans as Teoloog en Kerkman" te skryf. Uit die gang van die boek sal blyk dat hierdie „deurgaans" verdun het tot ongeveer een-tiende van die totale inhoud. As die skrywer net vir tuis-verbruik geskryf het, sou mens nie verplig gevoel het om op sy werk te reageer nie... hierdie diskussie is in Suid-Afrika so aan die orde van die dag... maar hy verklaar nadruklik dat hy hom rig ,tot die buiteland sowel as tot die binneland". Dit word ernstig. Dit verplig elke teoloog en elke kerkman en trouens elke verantwoordelike Suid-Afrikaner om dan toe te sien dat naas die binneland ook die buiteland 'n suiwer beeld ontvang oor die aktiwiteit van Teologie en Kerk in ons vaderland. Die goeie naam van die Kerk en die wetenskaplike peil van die Teologie in Suid-Afrika is daarmee gemoeid. Die Suid-Afrikaner moet hom ook nie troos met die gedagte dat die buiteland hom dalk nie veel sal steur aan hierdie werk nie. So direk en in sulke onomwonde taal val Prof. du Preez persoonlikhede, instellinge en die Kerk in die buiteland aan, dat hy hulle as 't ware uitdaag om te antwoord. Mens kan op grond daarvan verwag dat die werk groter aandag sal geniet as

\footnotetext{
* Die Redaksie verklaar dat die inhoud van hierdie artikel uiteraard vir rekening van die outeur bly.
} 
wat dit verdien. Maar ook met die oog op die binneland moet erns gemaak word met die beoordeling van hierdie boek. Die skrywer sluit dit namelik af met ' $n$ rassekundige kortbegrip van 93 stellinge in die vorm van vrae. Daaruit kan afgelei word dat die werk bestem is vir die gebruik by kategetiese, skoolse of dalk universitêre onderrig. Kerk, teologie en onderrig moet so 'n wetenskaplike aanspraak wetenskaplik weeg.

So 'n wetenskaplike oorweging is in hierdie geval 'n moeisame taak want die kritiese leser sal van die 272 bladsye nie een vind wat hy sonder kritiek kan omblaai nie. En ek bedoel daarmee nie die drukfoute waarvan die werk origens wemel nie. Ek bedoel ook nie in die eerste plek die oormaat van Germanismes en stylfoute nie. By 'n ewentuele herdruk en aan die hand van die kritieke kan die skrywer dit altyd herstel. Tussen hakies, 'n herdruk sal dalk nodig wees want die gerug wil dat die regering 'n groot deel van die eerste oplaag opgekoop het. Ek bedoel in die eerste plek die hantering van die feite-materiaal, die interpretasie van die geskiedenis, die gebruik van bronne en die manier van redenering.

Omdat die outeur van Die Skriftuurlike Grondslae van Apartheid ook in hierdie boek, in sy hoedanigheid as Kerkman en Teoloog die Skrif plek-plek ter stawing van sy argument inroep, is dit noodsaaklik dat sy eksegese ge-eksegetiseer word. Daarsonder sou tenminste die buiteland 'n totaal eensydige indruk kry van die beoefening van die Skrif-eksegese in Suid-Afrika.

Met ' $n$ captatio benevolentiae wat op bls. 2 begin en deur sydelingse teregwysinge aan die adres van Keet, Marais en andere deurvleg tot op bls. 19, gee die skrywer te kenne hoe die Skrif moet gebruik word en hoe die Kerk moet optree teenoor volk en staat. Die Kerk het, so stel hy, die roeping om profeti ss te sê, ,So sê die Here". In die trant van Eseg. 3:17 en Spr. 14-34 moet die Kerk en die Teologie aan volk en staat sê dat geregtigheid 'n nasie verhoog. Die teoloog moet die taal van die Bybel praat, niks meer en niks minder nie, maar hy moet daarteen waak om nie te verval tot „illegitieme" gebruik van God's Woord nie..." of tot ,verabsolutering van die raadgewinge nie". Wat beteken die laaste? Wil dit die deur oophou om te ontkom aan die volstrektheid van die eis van God's Woord? Wat is die verabsolutering van die raadgewinge van daardie Woord waarteen die teoloog moet waak?

Op bls. 60 begin hy sekere voorlopige gevolgtrekkinge te makk uit die Pinkstergeskiedenis van Hnd. 2:1vv. Hy stel daar dat die Naturellekultuur hoogstaande is en dat dit ' $n$ veel beter begrip van gemeenskap het as die Christendom van die Weste wat sekere rykdomme van die koinonia wat op Pinkster openbaar is, verloor het. Laat elke leser wat vertroud is met die Naturelle-kultuur en met die Westerse Christendom, oordeel oor die houdbaarheid van hierdie stelling, solank in gedagte gehou word dat Christelike gemeenskap universele gemeenskap beteken en nie die stam- 
lojaliteit wat Prof. du Preez as voorbeeld aanhaal nie. Sy bedoeling met hierdie en ander Skrif-uitsprake is om die Skrif te laat getuig ten gunste van rasse-skeiding in alle betrekkinge en ook in die kerklike betrekkinge. Sy sentrale gevolgtrekking staan op bls. 105: Die Skrif leer dat ,die eerbiediging en normale ontwikkeling van die eiesoortige in die gemeenskap onontbeerlik is vir die Skriftuurlike leer van eenheid-in-verskeidenheid." Om dit te bewys begin hy op bls. 68 met die verklaring dat die Nutestamentiese bedeling die bestaan van aparte volke glad nie opgehef het nie en hulle grense nie uitgewis het nie. "Die taalwonder op die Pinksterdag bevestig dit (Hnd. 2:8)". Op bls. 109 word hierdie Skrifgedeelte weer aangehaal: „Etniese groepering van Kerke” is geoorloof op grond van Hnd. 2:6-11. Op sterkte van vs. 11, ,,ons hoor hulle in ons eie taal oor die groot dade van God spreek”, verklaar hy, „Hier het klaarblyklik van God's kant 'n erkenning van die verskeidenheid-in-die-eenheid...'n erkenning van die verskeidenheid en die eerbiediging van die verskillende volke se eie aard en eie taal" gekom en weer, „,dit sou 'n berowing van die voorreg van God's groot dade in ons eie taal" wees as ander-talige volksgroepe geforseer word om in dieselfde erediens saam te wees". Iewers het Prof. Marais gestel, „Deur die taalwonder is die verskillende groepe nie van mekaar geskei nie, maar veel nouer saamgetrek. Die skeidsmuur van die taal waarmee God die sondige mensheid by Babel gestraf het, word deurbreek ... hul het nie hul (taal)-identiteit verloor nie, maar hul apartheid het weggeval." Die skrywer verklaar daarteenoor vierkantig dat die skeidsmuur van taalverskil nie deurbreek is nie of anders moet die taalwonder hom voortdurend herhaal. Hy vervolg, „Dit dan is die werklike grond vir aparte kerke in Suid-Afrika, namelik nie die sondige onwilligheid van mense om saam te aanbid nie (dit moet natuurlik altyd bekamp word) maar die feit dat verskillende volksgroepe elk na eie taal en kultuuraard moet bearbei word". (bls 254).

Ons handel eers die bykomstige stellinge af om dan tot ' $n$ nadere ontleding van Hnd. 2 oor te gaan. Ons begin ook sommer by die laaste opmetking: Kerklike apartheid berus nie op die sondige onwilligheid van mense om saam te aanbid nie: Ek meen tog dat Prof. du Preez in hierdie boek'n paar maal die verklaring van die Sinode van 1857 aanhaal, dit eenkeer selfs noem ,'n voorvaderlike beleidsverklaring"; dat hy eenkeer ook die verklaring van die Sinode te Pretoria in 1957 aanhaal. En beide Sinodes verklaar presies wat die skrywer nou ontken! Hulle sê met soveel woorde dat rasse-skeiding in die Kerk toegelaat moet word op grond van die vooroordele en die swakhede van die Blankes wat beswaar maak teen erediens en avondmaalsviering saam met Nie-Blanke gelowiges. Dan, dat dit 'n berowing van die voorreg sou wees om die Evangelie in hul eie taal te hoor as anderstaliges geforseer word om saam te wees in dieselfde erediens. Met 'n aanhaling van Beerekamp wys hy daarop dat perslot 
in Nederland die Nederlands Hervormde Kerk en die Waalse Kerk naasmekaar staan. Eerstens al, nie Proff. Marais en Keet of die Wêreldraad wil enige anderstalige ooit forseer om 'n erediens in 'n Afrikaanstalige Kerk by te woon nie, maar hulle en talle andere protesteer daarteen dat die anderstalige, en dit nie eers om sy taal nie maar om sy huidskleur, geforseer word deur Kerklike en Staatswetgewing om so 'n erediens saam met Blankes nie by te woon nie. 'n Swakker illustrasie van taal- en rasse-apartheid in die Kerk as die voorbeeld van die Hervormde en Waalse Kerke kon die skrywer nie gekies het nie. Eerstens, 90 persent van die ,,anderstalige" Nederlanders wat na die Waalse Kerk gaan, waar die erediens in Frans gehou word, praat Nederlands. Tweedens, niemand forseer hulle om daarheen te gaan nie, maar ook niemand forseer hulle om nie daarheen te gaan nie. Die voorbeeld bewys presies die teenoorgestelde van wat die skrywer be-oog.

En met sy verwysing na Hnd. 2 is dit dieselfde geval: dit bewys presies die teenoorgestelde as wat Prof. du Preez dit wil laat sê. Seker, die Nutestamentiese bedeling het die bestaan van aparte volke nie opgehef nie, maar Hnd. 2 kan nie as bewys vir so 'n stelling aangevoer word nie, want op die Pinksterdag was daar nie sestien verskillende nasies saam soos Prof. du Preez meen nie, maar net Jode! Vers 5 sê dit uitdruklik, vers $10 \mathrm{~b}$ impliseer dit en in vers 22 noem Petrus hulle ,Israeliete”, so-ook in vers 36; hy en hulle noem mekaar in verse 29 en 37b ,broeders", die aanspreekvorm van Jood teenoor Jood, en bietjie later, van Christen teenoor Christen, lede van die nuwe Israel. Die hoofstuk sê dus presies niks oor rasseskeiding in die Kerk nie. As vers 39 iets impliseer, dan sê Petrus daar dat God sy volk tot 'n eenheid sal versamel uit Jode en „die wat daar vér is, die wat $\mathrm{Hy}$ tot Hom sal roep". In die Joodse idioom beteken „die wat daar vér is" die anderstalige, anderslykende, anderrassige heidene. Die noem van die ,nasies" in die hoofstuk sê niks meer nie as dat hulle almal Jode uit die verskillende Diaspora-lande was.

Hnd. 2 rapporteer inderdaad 'n taal-wonder, maar 'n taal-wonder met weereens presies die teenoorgestelde betekenis as wat Prof. du Preez daaraan wil gee wanneer hy praat van 'n ,taalgrens" wat skeiding in die Kerk op grond van taalverskil vereis. Die sprekers op daardie oggend was almal Galileërs. Dit grens hulle egter nie af van die sestien soorte andertaliges nie, maar deur God's Gees--en die Gees van God is nog steeds by die Kerk of die Kerk is nie meer Kerk nie-spreek hulle juis die Evangelie anderstalig. In die Kerk bestaan daar kragtens Hnd. 2 en juis kragtens Hnd. 2 nie so-iets as ,taalgrense" en dit nota bene as rede tot rasse- en taalskeiding in die Kerk nie. Ook hierin bewys Hnd. 2 dat Prof. Marais gelyk het en Prof. du Preez God's Woord verkeerd uitlê. Daar is laastens nog een elementjie in hierdie hoofstuk wat die geleerde skrywer se aandag ontsnap het. Dit is dat God Kerk maak en dat God 
sy Kerk versamel. Kerk beteken uitgeroepenes, deur God geroepenes, van vér af, oor taal- en rasse-en nasionale-grense deur God nader geroepenes sodat dié wat vér was en dié wat naby is, voortaan één, en sigbaar een sal wees soos Paulus dit ook stel in Ef. 2:11vv. Maar Hnd. 2 sê dit ook in vs. 39 en weer in vs. 47b. Soos ek hierdie Skrifgedeeltes lees, as God saamroep, het Prof. du Preez of 'n kerklike groep of 'n ow'erheid in 'n christelike land nie die reg om te skei nie, en het verder geen deel van die Kerk die reg om op grond van kleur-, kultuur-, en taalverskil ,etniese” of enige soort kerke te ,stig" nie. 'n Kerk word nie ,gestig" deur eensoortige mense vir andersoortige mense nie. Die één, heilige algemene Christelike Kerk is gemaak en word gemaak deur God. 'n "Kerk" wat "kerke" stig waag baie; hy is miskien nie bewus daarvan nie dat hy hom plaas in die plek van God.

Dit gaan al nie beter met die verdere tekste wat die skrywer aanhaal ter ondersteuning van sy stelling nie. Nog steeds op bls. 68 verklaar hy, ,En die laaste bevel van Jesus ... veronderstel die voortbestaan van afsonderlike volke (Mt. 28:19; 24:14)". Sekerlik, maar die voortbestaan van volkere het absoluut niks op grond van hierdie tekste te doen met die opdeling van die Kerk in etniese, taal- en kultuurkerke nie. Die sendingbevel van die Here bedoel presies die teenoorgestelde, namelik dat die Apostels dissipels moet maak, d.w.s. lidmate van die één, algemene Kerk, van mense uit al die nasies. En dat dit die bedoeling van die teks is, blyk nie alleen uit die inhoud van die Griekse woord, matheteusate, nie maar met name uit die volgende teks wat die skrywer aanhaal, Mt. 24:14. Die Evangelieverkondiging be-oog nie om alle nasies dissipels te maak nie, maar om vóór alle nasies te getuig sodat uit daardie nasies een nuwe heilige Godsvolk, 'n splinternuwe nasie, te voorskyn sal kom. En van hierdie nasie getuig die Skrif en eis die Skrif dat hy hier en in die geskiedenis en sigbaar één sal wees, nie soos Prof. du Preez wil, een-inverskeidenheid nie, maar één in weerwil van verskeidenheid.

Net dieselfde geld van die volgende twee tekste wat aangehaal word, Openb. 5:9 en 7:9. Dit spreek van die verenigde gemeente wat God loof en wat tot daardie eenheid versamel is uit al die nasies en tale en tonge. Etniese grense en taalgrense bestaan vir die eenheid van die Kerk van Christus nie; die eenheid bestaan en moet bestaan in weerwil van daardie "grense". Die laaste twee tekste, soos meermale die geval met tekste deur Prof. du Preez aangehaal, t.w. Openb. 14:16 en 19:15 het met die saak onder bespreking niks te doen nie, nie eers in die teenoorgestelde rigting nie.

Op bls. 64 vind die skrywer in Rom. 15:12 en I Kor. 15:21 die nodige grond vir sy stelling dat die Skrif die eenheid van die menslike geslag leer, i.s.v. alle mense in Adam aangetas is deur die sonde en alle mense deur 
die tweede Adam, Christus, die verlossing ontvang. Nou, oor erfsonde en verlossing, soos die skrywer meen, handel hierdie twee tekste glad nie. Byna toevallig staan die eerste een, te wete $\mathrm{Rm}$. 15:12 in 'n hoofstuk waarin Paulus feitlik niks anders doen nie as om die gemeente van Rome, wat uit tenminste drie taal-, kultuur- en rassegroepe bestaan het, namelik Jode, Grieke en Romeine (en die ou graf-inskripsies laat mens dink dat daar ook 'n hele aantal Noord-Afrikaners van onbepaalbare kleur by was) tot eenheid op te wek in weervil van hul verskeidenheid. En moet nou nie dink aan 'n eschatologiese eenheid in ' $n$,,onsigbare" kerk in 'n mistieke verbondenheid nie. Die ,julle" wat hy in die jaar 56 n.C. in hierdie brief anspreek, is onmiskenbaar sigbare en lewendige mense op die aarde in die gemeente te Rome; en aan hulle skryf hy, (vs. 5-7) ,En mag die God van volharding en bemoediging aan julle gee om eensgesind te wees ondermekaar ooreenkomstig die wil van Christus Jesus, sodat julle die God en Vader van ons Here Jesus Chrustus eendragtig uit een mond kan verheerlik! Neem daarom mekaar aan,..." Hierdie ,mekaar" word uit vs. 9-12 duidelik; dis Christene uit die Joodse ras, taal en kultuur aan die eenkant en Christene uit die heidense tale, rasse en kulture aan die anderkant. Vir Paulus is die Christenvolk oor alle denkbare menslike grense heen, één en dit beteken sigbaar een in die historiese en daarom sigbare gemeente te Rome.

Merkwaardigerwys word op bls. 64 en bls. 101 ook I Kor. 15:21 en 45 aangehaal om die goeie reg van rasseskeiding in Kerk en maatskappy te billik. Die betrokke hoofstuk het in sy geheel egter niks te doen met taalgrense en rasse nie maar met die wyse van die opstanding uit die dode en die aard van die opstandingsliggaam. Op dieselfde manier haal die skrywer dieselfde teks aan op bls. 105 waar hy stel, „Die beelde wat vir die Kerk van Christus gebruik word, leer duidelik die verskeidenheid in die eenheid sowel as die feit dat dit moet bly voortbestaan". Om die leser homself te laat oortuig dat I Kor. 15 regtig nie grond gee vir so ' $n$ bewering nie, moet hy naas vers 21 tot 41 ook lees verse 42-54 en 12 en 35. Paulus antwoord hier op die vraag van die Korinthiërs oor die feit en die aard van die opstanding uit die dood en nie op 'n vraag oor die reg al dan nie om rasse- en taalskeiding in die Kerk aan te bring nie.

Maar vir sy stelling voer die skrywer verder ook I Kor. 12:12-27 en Rom. 14:4-5 aan. Weereens hierdie tekste het regtig niks te doen met 'n onsigbare mistiese eenheid binne 'n sigbare taal- en rasverskeidenheid nie, maar beide handel oor die verskeidenheid van ampte binne die selfde gemeente op grond van die verskeidenheid van genadegawes. Prof. du Preez wil die verskeidenheid terugvoer op fisiese onderskeide tussen gelowiges wat die reg sou gee tot die stigting van etniese kerke. Maar Paulus begin hierdie hoofstuk met, „Wat die geestelike gawes betref, 
broeders...". Hy praat nie oor taal, kultuur en etniese en kleurgrense nie maar oor die verskeidenheid van bedieninge en werkinge (vs. $4,5,6$ ) binne dieselfde gemeente; sommige het die gawe van gesondmaking en andere weer die gawe van profesie en sommige het die Pinkstergawe van allerhande tale (vs. 10). Sover is dit van Paulus om in hierdie hoofstuk te bedoel wat Prof. du Preez daarin lees, dat hy aan die gemeente van Korinthe skryf dat hulle, bestaande uit verskillende etniese groepe, in dieselfde sigbare gemeente sigbaar een moet wees: „Want ons is almal ook deur een Gees gedoop tot een liggaam-of ons Jode of Grieke is, slawe of vrymanne;". En dis presies wat hy ook skryf aan die ,gemengde" gemeente van Rome in Rom. 12:4-5.

Prof. du Preez se keuse van tekste vir sy Skriftuurlike bewysvoering ten gunste van apartheid in die Kerk is nie oortuigend nie; dit bewys sover of niks óf presies die teenoorgestelde van wat hy beweer. Sodat niemand die waaghalsigheid sal hê om die liggaam van Christus met menslike hand en menslike willekeur te verdeel nie, wys ek in dieselfde I Kor. 12 nog op vs. 24: „Maar God het die liggaam saamgestel en aan die misdeelde lid oorvloediger eer gegee...". Wat God, in weerwil van geslagtelike, sosiale en etniese en kulturele en spraaklike onderskeide saamgevoeg het, mag die mens nie skei nie. Dis wel waar dat die skrywer op bls. 106 die eenheid erken maar hy sublimeer dit eerstens tot 'n ,geestelike eenheid", dus 'n eenheid wat ons in ons sigbare bestaan nie raak nie; en hy konkludeer selfs dat aangesien die eenheid van die Kerk werk van God's Gees is, ,kan dit daarom nie deur menslike bemoeiing bewerk of afgedwing word nie". Seker nie. Maar niemand wil die eenheid op enig iemand ,afdw'ing" nie. Alleen die pleidooi in hierdie boek, w'il die sigbare verwerkliking van hierdie eenheid van die Kerk deur Gods Gees nie toelaat nie.

Met die skrywer sit ons die ondersoek van die Briewe van Paulus aan die Korinthiërs voort. Op bls. 106 verklaar hy dat die Bybel nie eis dat iemand om Christen te wees, gedenasionaliseer moet word nie en hy beroep hom op II Kor. 4:5. Sekerlik nie, maar die Bybel eis ook nie dat iemand tot 'n kleureensoortige, kultuur-eienaardige ras-eiesoortigheid genasionaliseer moet word om Christen te word nie. Niemand eis die denasionalisering van enige gelowige in Suid-Afrika nie, maar Prof. du Preez, as voorstander van eiesoortige ontwikkeling, eis presies dat hulle genasionaliseer word tot eiesoortige christelik-nasionale kerke! Daar moet tussen hakies op gew'ys word dat die skrywer hom voortdurend bedien van hierdie negatiewe debatstegniek wat absoluut waardeloos is vir enige diskussie. Mens kan met hierdie tegniek enigiets ,,bewys", byvoorbeeld dat 'n poliesman 'n helmet moet dra omdat die Skrif nie vereis dat 'n poliesman 'n pet moet dra nie. Maar om terug te kom by II Kor. 4:5. Dit het absoluut niks te doen met nasionalisering of denasionalisering nie want 
Paulus verdedig daar sy apostelskap. Sy teenstanders sê dat hy homself verkondig en nie Jesus Christus nie. Hy antwoord, ,W Want ons verkondig nie onsself nie, maar Christus as Here, en onsself as julle diensknegte om Jesus ontwil". Nie 'n woord oor nasionalisme of denasionalisasie nie!

Op dieselfde bls. 106 haal die skrywer Hnd. 15:28-29 aan en kom met dieselfde tegniek van negatiewe stelling tot die slotsom, „En by die Eerste Sinode (Hnd. 15) word besluit om vir die heidene wat hulle bekeer tot die Christendom nie te vereis dat hulle eers verjoods moet word deur besnydenis en onderhouding van die Joodse wet nie, maar dat hulle hul moes onthou van die sondes van die heidendom". Heeltemal reg, maar daardie Eerste Sinode vereis ook nie dat hulle eers nasionaal moet stol in eiesoortige taal- kultuur- en etniese groepe voordat hulle Christene kan word nie. Inteendeel, Hnd. 15:14 stel 'n klinkende "nee" teenoor alle nasionaal-eiesoortige "kerke" wanneer Jakobus die resultaat van die besprekinge opsom met die woorde, (ek vertaal die grondteks), „Manne, Broeders, luister na my! Simeon het verklaar hoe God eers gekyk het om uit die nasies ' $n$ volk vir sy Naam te neem". En dit is presies wat Kerk en Christendom is, één ongedeelde sigbare volk wat God uit die nasies versamel vir Sy Naam. Voormalige nasie- kultuur- taal- en etniese gebondenheid het deur die uitverkiesing van God vir die samestelling van sy volk, d.i. sy Kerk, hier op die aarde (die Sinode handel tog nie oor 'n onsigbare Kerk, 'n geestelike en mistieke liggaam nie) absoluut alle betekenis verloor. Volgens vs. 16 en 17 stel God hierdie volk uit die Jesajaanse res van Israel en uit die nasies saam. So min agting het die vergadering vir etniese yweraars gehad, dat hy die enigste voorstanders van so 'n etniese verdeling van die Kerk in Antiochië skriftelik teregwys en veroordeel (vs. 24vv.).

Die skrywer keer op bls. 108 terug tot I Kor. 12 en voeg Joh. 15 by om te verklaar dat die wesentlike elemente van die Kerk die gemeenskap met gelowiges in Hom is en dat daardie gemeenskap meer fundamenteel is vir die wese van die Kerk as sy organisasie. Dis waar. Maar dan vervolg hy met die nou-al bekende tegniek van negatiewe stelling dat dit daarom nie nodig is om veelrassige gesamentlike dienste, 'n kunsmatige demonstrasie van die eenheid, te hou nie. En dis nie waar nie. Eerstens al, 'n erediens waaraan mense van verskillende rasse deelneem, is nie 'n kunsmatige demonstrasie nie maar die normale beoefening van die Christelike taak, die lof-offer aan God wat nie 'n ,,aannemer van die persoon" is nie. Verder, dis om ongelyksoortighede bymekaar te haal om te praat van 'n „,veelrassige gesamentlike erediens"; want die Christelike Kerk is uit die hemel der hemele gegee en die veelheid van rasse is so aards as die aarde self. Die Kerk is nie veel- of enkelrassig nie, dis God's volk wat Hy uit die nasies of rasse tot 'n sigbare eenheid versamel het. Dis derdens verkeerd, omdat die negatiewe stelling van Prof. du Preez impliseer dat 
verdedigers van die ondeelbaarheid van die Kerk 'n erediens nie as sodanig erken tensy dit deur meerdere rasse bygewoon word nie. Dis vierdens verkeerd omdat I Kor. 12, soos ons hierbo aangetoon het, niks te doen het met rasse nie, maar met die eenheid van die één gemeente te Korinthe in weerwil van en selfs omrede van hulle onderskeie gawes van die Heilige Gees.

Nog 'n keer op bls. 135 roep die skrywer I Kor. tot getuienis en hierdie keer hfst. 7:17-24 vir die stelling, ,,Volgens die Woord van God is die beskouing dat die Christendom die verskille in ras, volk en stand wil uitwis, beslis verkeerd". Hierdie soveelste aanwending van die debatstegniek van die negatiewe stelling sou volkome juis gewees het as daar iemand was wat beweer dat die Christendom die verskille in ras, volk en stand wil uitwis. Daar is nie iemand wat soiets beweer nie; altans, Proff. Marais, Keet en die Wêreldraad van Kerke beweer dit nie. Maar soos meermale, was ook hierdie Skrif-aanwending besonder ongelukkig vir die skrywer se doelstelling. Hy wil daaruit kristalliseer die Skriftuurlike toestemming om die Kerk op rasse-nasionale- en kultuuronderskeide te skei, en so 'n skeiding op daardie gronde is presies $u$ at Paulus verbied. Teneinde ' $n$ gemeente van ras- en sosiale gelyksoortiges te hê, wou sommige Jode in die gemeente hul besnedenheid ongedaan laat maak; omgekeerd was daar gelowiges uit die heidendom wat in die trant van die Jerusalemse Judaiste hul wou laat besny; daar was base in die gemeente en daar was ook slawe en laasgenoemdes vra of hulle nie, teneinde aan dieselfde gemeente as hul base te behoort, hul moet inspan om hul vry te koop nie. As Paulus nou Prof. du Preez was, sou hy geantwoord het dat hulle ten alle koste eiesoortig moes bly en dat hulle liewer etniese kerke moes ontwikkel en dat hulle nie kunsmatige demonstrasies van gesamentlike eredienste moes hou nie maar hulle tevrede moes stel met 'n ,geestelike eenheid" wat eendag, om presies te wees, op die laaste dag, sal oorgaan tot 'n sigbare eenheid by die plene esse van die Kerk. Maar Paulus beveel hulle nie om 'n geestelike eenheid-in-fisiese geskeidenheid te beoefen nie. Hy sê dat hul rasse- en sosiale onderskeidenheid so relatief is dat elkeen in die gemeente van Korinthe moet bly in die staat waarin hy deur God geroep is (vs. 17-21). Paulus laat geen skeiding in die gemeente van Korinthe toe op grond van etniese en sosiale onderskeide nie. En die gemeente van Korinthe vorm nie 'n uitsondering nie want in vs. 17 sê hy, „En so bepaal ek in al die gemeentes". Jammer dat die skrywer hierdie Skrifgedeelte vir sy argument aangehaal het; dit bewys niks meer nie as dat Paulus se gemeentes, al sy gemeentes, in die taal van die skrywer, „gemengde" gemeentes was wat iedere Sondag by die liefdesmaal en die Avondmaal en onder die prediking van die Woord 'n ,kunsmatige" demonstrasie van eenheid-in-weerwil-van-onderskeid gegee het. 
Die skrywer vervolg, „Paulus wil die eenheid van die gemeente en nie die gelykheid nie. A. Schlatter sê in verband met die strewe na gelykmaking in die gemeente: „Dit beteken dan dat die man en die vrou hul manlikheid of vroulikheid verloën..." Schlatter het heeltemal reg, maar nie Prof. du Preez nie; want Schlatter stel dat nie die eendersheid van die gemeente gevra word nie maar sy eenheid. D.w.s. sy eenheid in weerwil van die feit dat die lidmate nie eenders is nie. En dit is nog steeds presies die teenoorgestelde van wat Prof. du Preez wil!

Maar die voorbeeld van die "man-en-vrou" word weer deur die skrywer aangehaal op bls. 67 met verwysing na Gal. 3:28 en Kol. 3:11. Trouens dis 'n oorbekende argument van hulle wat die Kerk etnies wil verdeel en wat graag die Apostel se bevel tot eenheid in die betrokke twee briefgedeeltes w il ontsenu. Hulle en Prof. du Preez redeneer so: As Paulus bedoel dat daar in die Kerk geen onderskeid gemaak moet word tussen Jode en Grieke, slawe en vrymanne en mans en vrouens nie en dat hulle 'n sigbare kerklike eenheid moet vorm, dan moet dit ook beteken dat man en vrou voortaan eenders sal wees en dit is in die feitelikheid onmoontlik; dus Paulus vereis nie die sigbare eenheid van die Kerk nie en dus staan dit ons vry om die Kerk na willekeur op te deel in etniese Kerke van Grieke en Jode en Scithe en in sosiale kerke van werkgewers en werknemers. Nou maak hierdie logici 'n paar kardinale foute: Eerstens, Paulus vra nie die eendersheid van alle Christene nie maar die eenheid; tweedens, die "logiese" konsekwensie moet verder deurgetrek word en as mens vir al die nasionale groepe en sosiale groepe wat Paulus noem, verskillende ,kerke” wil „stig”, dan moet mens ook verskillende kerke stig vir mans en vir vrouens! Die eenheid wat Paulus wil, illustreer hy met opset met die voorbeeld van man en vrou: En man en vrou vorm so 'n sigbare en tasbare eenheid in weerwil van verskeidenheid soos weinig. Volgens die logici van die aparte kerke kan man en vrou dan ook maar 'n mistieke abstrakte onsigbare eenheid vorm wat hul eenheid so af en toe laat sien in die vorm van oor-en-weer representasie en wat origens elkeen op sy en haar eie terrein apart en eiesoortig ontwikkel. Kol. 3:11 en Gal. 3:28 sê volgens alle maatstawwe van eksegese presies die teenoorgestelde as wat Prof. du Preez dit wil laat sê.

Hy vervolg, „Bowendien kan niemand tog ontken dat hierdie eenheid in Christus sy finale realisering alleen in die eskatologiese, in die hiernamaals kan vind nie..." Ek kan en wil dit graag ontken. Sonder om weer 'n keer daaro? te wys dat al die gemeentes waaraan Paulus geskryf het ,gemengde" gemeentes was en dit histories nawysbaar hier op die aarde was en nie in die hiernamaals nie, al die gemeentes van wie Paulus eis dat hulle in weerwil van die etniese, kulturele en sosiale onderskeide één sal wees, wil ek in die eerste plek stel dat Kerk, volgens die Skrif, essensieël tot die historiese terrein behoort en dat wanneer die historie 
ophou, die Kerk oorgaan in Koninkryk van die Hemele. In die hiernamaals is daar nie „Kerk” nie, net Koninkryk. Die voorstelling dat die eenheid van die Kerk wat deur die Skrif vereis word, tot die „Kerk in die hiernamaals" behoort, is dus vals. Tweedens, die Kerk in die Nuwe Testament is die voortsetting van die Kerk in die Ou Testament, d.w.s. van die uitverkore volk van God. En daarom is die Christelike Kerk netso sigbaar as wat die volk van God in die Ou Testament sigbaar was en word van die Christelike Kerk netso 'n sigbare eenheid verwag as van die sigbare één Volk van God. Ten derde, die Nieutestamentiese woord vir Kerk is ,,ekklesia" en dit beteken die vergadering van dié wat God uitroep uit die wêreld om vir Hom 'n volk te wees.

Die eerste kern van hierdie Kerk wat Christus uitgeroep het uit die wêreld, was die dissipels. Vir hulle sê $\mathrm{Hy}$, ,Julle is in die wêreld maar nie van die wêreld nie". Dit beteken twee dinge vir die Kerk. Eerstens dat die Kerk nie moet konformeer na die wêreld met sy politieke, sosiale en etniese en kulturele indelinge nie en verder dat die Kerk regtig en fisies in die wêreld is, so fisies en sigbaar as daardie dissipele-groep. Van daardie eerste Christelike Kerk verwag Jesus volgens sy Hoërpriesterlike gebed dat hulle één sal wees en dat hulle dit in die wêreld sigbaar sal wees. Dis met betrekking tot die Elf-tal wat sigbaar en fisies in Gethsemane op daardie aand teenwoordig was dat Hy bid in Joh. 17:11 „En Ek is nie meer in die wêreld nie, maar hulle is in die wêreld;... Heilige Vader, bewaar in U Naam die wat U My gegee het, sodat hulle een kan wees net soos Ons." In die 14de tot 15de verse verklaar $\mathrm{Hy}$ voor sy Vader dat hierdie sigbare eenheid van dissipels, sigbaar in die wêreld, omrede van die Woord van God ,nie van die wêreld is nie". Vanweë hulle sigbare eenheid-nie uit een of ander ideologiese eenheidsstrewe of kunsmatige demonstrasie nie, maar uit gehoorsaamheid aan die wil en die Woord van God-voorsien Jesus dat hulle netso gehaat sal wees as $\mathrm{Hy}$ : ,,en die wêreld het hulle gehaat, omdat hulle nie van die wêreld is nie...", omdat hulle nie voldoen aan die slagspreuke en politieke krete van die wêreld nie.

Daardie dissipele-groep, die embrio van die Christelike Kerk (vgl. Ef. 2:19 vv.), nie gelykvormig aan die wêreld nie, maar in die wêreld, is blywend in die wêreld gestuur deur die Here (vs. 18). Kerk beteken om in die wêreld te uees sonder om wêreldgelykvormig te word, en om in die wêreld gestuur te wees en om met sy eenheid en sy gesondenheid deur God, voor die weêreld te betuig dat Jesus die Christus die gesondene van God in die wêreld was. Die eis van die sigbare. eenheid hier in die wêreld-nie eers in die hiernamaals in die "onsigbare Kerk" nie, beperk Jesus nie tot die etnies en sosiaal eiesoortige Galilese vissers nie maar, „Ek bid nie vir hulle alleen nie, maar ook vir die wat deur hulle woord in My sal glo-dat almal een mag wees netsoos $U$, Vader, in $\mathrm{My}$ en $\mathrm{Ek}$ in $\mathrm{U}$; dat hulle ook in ons een mag wees, sodat die wêreld 
kan glo dat U my gestuur het." Eintlik moet mens die laaste sinsdeel onderstreep: Die vereiste sigbare eenheid in die wêreld is nie 'n doel in sigself of ' $n$ kunsmatige demonstrasie van die eenheid nie, maar getuienis -'n vir die wêreld sigbare getuienis dat Christus van God kom. In vers 23 bid $\mathrm{Hy}$, ,... sodat hulle volkome een kan wees; en dat die wêreld kan weet dat U My gestuur het.". Nou, die wêreld weet nie as hy nie gesien het nie en 'n onsigbare eenheid van die Kerk in die hiernamaals kan hy nie sien nie.

Die teologiese sin van hierdie eenheid van die Kerk gaan veel en veel dieper as 'n oppervlakkige en ,kunsmatige demonstrasie van eenheid": Die sigbare eenheid van die Kerk in die wêreld is die sigbare simbool van die eenheid van Christus met God; daardie simbool moet sigbaar wees, ,sodat die wêreld kan glo, (vs. 21), sodat die wêreld kan weet (vs. 23), ,dat Christus deur God gestuur is in die wêreld. Kortom, die sigbare eenheid van die Kerk is die simbool van die onsigbare eenheid van die Vader en die Seun, netsoos die sakramente die sigbare simbool is van die onsigbare eenheid en gemeenskap van Christus met sy Kerk. Maar Prof. du Preez het in een ding gelyk: die wêreld sal probeer om die Kerk uitmekaar te jaag in eiesoortige hokke: ,Kyk, die uur kom en het nou gekom dat julle uitmekaar gejaag sal word, elkeen na sy eie toe", (Joh. 16:32). Maar Prof. du Preez het nie gelyk wanneer hy leer dat die eenheid van die Kerk tot die hiernamaalse en die onsigbare behoort nie.

En hy het ook ongelyk wanneer hy in die Skrif twee direk teenoormekaarstaande lyne, die ,,sentrifugale" en die ,,sentripetale”, wil onderskei en die twee met mekaar wil versoen met die formule van ,eenheid-ingeskeidenheid" (bls. 100-102). So 'n hegeliaanse sintese van tese en antitese bestaan in die Skrif nie, want die Skrif ken alleen die tese en antitese tussen geregtigheid en ongeregtigheid en die twee kan netsomin gesintetiseer word as dag en nag. Nie een van die tekste wat hy aanhaal het betrekking op rasseskeiding in die Kerk nie, maar almal betrek hulle op die skeiding tussen gelowiges en ongelowiges. En die gelowiges, van watter ras en kleur ter wêreld ookal, vorm 'n sigbare eenheid in die wêreld.

Vir sy rasse-skeiding in die Kerk en teen Prof. Keet leer die skrywer verder op grond van die Skrif 'n kollektiewe verantwoordelikheid van volke en rasse (bls. 102 en 251). In die verbygaan mag ek daarop wys dat Hitler ook 'n rasse- en kollektiewe verantwoordelikheid geleer het om die feit te regverdig dat hy gyselaars geneem en doodgeskiet het. Prof. Keet stel, "moral judgement cannot be passed on the group as such but only on the individual. It is always the individual in the group who is responsible”. Prof. du Preez antwoord, „Die Bybel self is vol van voorbeelde van groepsbeoordeling. Kyk maar na Jesaja, 'n sondige volk word ge-oordeel". Sekerlik word 'n sondige volk ge-oordeel as die indiwidue waaruit daardie volk saamgestel is, soos één man aan God 
ongehoorsaam is. Maar dieselfde Jesaja verklaar in hfst. 56 dat God nie met groepe rekening hou nie maar met indiwidue (Jes. 56:2). Die etnies andersoortige vreemdeling wat hom in die geloof an God verbind, sal voortaan nie meer omrede van sy groepsverband sê, „Die Here skei my af van Sy volk nie" (Jes. 56:3-7). En hierdie laaste vers eindig met 'n uitspraak wat Jesus aanhaal in Mrk. 11:17: ,, My huis sal 'n huis van gebed genoem word vir al die nasies". Dis die sigbare huis van God, die versameling van sy één volk, onge-ag die groepsverband waaruit hulle voortkom. Wanneer Jeremia vooruit wys op die Nuwe Verbond wat God sal instel, verdwyn alle moontlike groepsverantwoordelikheid en die Here sê: , (onder hierdie Nuwe Verbond) sal elkeen vir sy eie ongeregtigheid sterwe. Elkeen wat groen druiwe eet, sy tande sal skurf word" (Jer. 31:29-31). Het Prof. du Preez nog verdere bewyse nodig van die korrektheid van die stelling van Prof. Keet? Ja, want hy voer ook 'n sin van Spiegel-Schmidt aan: „Es gibt eine echte Kollektivverantwortung die in der Blutrache deutlich werd". Dis beste geantwoord met 'n vraag: Be-oefen die Christen, Schmidt, nog die bloedwraak en beveel Prof. du Preez terwille van die behoud van die kollektiewe verantwoordelikheid die beoefening van die bloedwraak aan?

Maar tengunste van opdeling van die Kerk in 'n menigte etniese, kleur- en taalgroepskerke, roep die skrywer nog 'n aantal Nutestamentiese tekste tot getuie van groepsverantwoordelikheid, t.w. Mt. 23:15, 23; Mt. 11:20-24; Openb. 2-3, en hy verklaar na aanleiding daarvan, "Selfs in die mond van Jesus hoor ons groepsbeoordeling...". Kom ons ondersoek hierdie ,groeps-beoordelinge". Mt. 23:15, 23 en 11:20-24 is 'n wee oor die Skrifgeleerdes en Fariseërs, nie omdat hulle tot die "groep" van die Skrifgeleerdes en die Fariseërs behoort nie, maar omdat hulle die eis van die kinderlike gehoorsaamheid aan God afkoop met uiterlike maatreëls, soos die gee van koljander en anys en komyn, en omdat hulle die lewende Godsgeloof vervang met 'n interkontinentale propaganda van uiterlike wetsonderhouding. Buitendien, hierdie twee groepe konstitueer nie 'n aparte ras of 'n etniese kultuurgroep nie, hulle is gewone Jode soos al die ander. Dis ironies, maar in die oorspronklike beteken die naam, „Fariseër”, separatis. Verder, dat Jesus nie die Fariseër veroordeel omrede van sy groepsverband nie, blyk uit die feit dat die voormalige Fariseër, Paulus, een van sy grootste apostels geword het.

Mt. 11:20 v. en Openb. 2-3 help die skrywer se argument netso min. In die eerste teks spreek Jesus ' $n$ wee uit oor die stede Górasin, Bethsaida en Kapérnaum wat sy wondere met hul oë gesien het en ongelowig gebly het. Dit het te doen met die ongeloof van hele stede maar seker niks met 'n kollektiewe verantwoordelikheid, en via laasgenoemde, met die opdeling van die Kerk in etniese groepsverbande nie. Netso bestraf die Here in Openb. 2-3 die sewe ongehoorsame gemeentes, om die on- 
gehoorsaamheid van die individuele gelowiges daarin en nie omrede van groepsverantwoordelikheid nie.

Oor die eenheid van die Kerk spreek die skrywer hom op bls. 107 as volg uit: „Die eenheid van die Kerk bestaan volgens die Skrif daarin dat mense deur die gemeenskaplike geloof in Christus met mekaar verbind is as lede van dieselfde mistieke, geestelike liggaam... Die gelowiges wat in die Kerk is, is broeders en susters, nie kragtens hul gemeenskapssin, hul eensgesindheid, hul broederlike liefde nie, maar kragtens die feit dat die een Christus vir Hom een Kerk versamel het... Die eenheid van die Kerk is geheel objektief gefundeer in Christus en nie subjektief asof dit berus op die gesindheid van mense nie. Uit die Skrif is dit duidelik dat die eenheid van die Kerk nie alleen deur Jesus verlang word nie (Joh. 8:35; 10:16; $17: 21$ ) maar dat Hy dit ook verwerklik (van NifTrik, Kleine Dogmatiek)...". Dit is alles in mindere of meerdere mate juis. Dit is te min juis as die skrywer met die nadruklike toevoeging dat die Kerk 'n mistieke, geestelike liggaam is, wil impliseer dat die eenheid van die Kerk hom dus nie in die sigbare wêreld sigbaar hoef te openbaar nie. Dit is ook te min juis as hy met die toevoeging dat die Kerk geheel objektief in Christus gefundeer is, impliseer dat ons daarom as die subjekte ontslaan is van die gehoorsaamheid jeens sy gebod dat ons sigbaar een moet wees. Ook sy aanhaling uit vaN NIFTRIK se Kleine Dogmatiek is te min om juis te wees, want op bls. 82 van daardie selfde werk verwerp vaN Niftrik netsoos Barth die voorstelling van die onsigbare Kerk wat Prof. du Preez huldig, radikaal.

Bywyse van toegawe is die skrywer op bls. 110 bereid om die sigbare eenheid van die Kerk as ideaal te handhaaf, d.w.s. as onverwerklikbare ideaal en hy beroep hom daarvoor op Hnd. 6:1 vv.: „In die Nutestamentiese tye is die ideaal van die eenheid in verskeidenheid in die sigbare Kerk nie bereik nie. In Jerusalem is die weduwees van die Griekssprekendes uitgespeel teen die Hebreërs... Apollos-aanhangers het in Korinthe teenoor die Sefasvolgelinge gestaan (I Kor. 1:10 vv.) en oral het JodeChristene teenoor die heiden-Christene gestaan... Om die redes is ook die Christelike gemeentes in Duitsland, Holland en Frankryk nie op internasionale grondslae georganiseer nie, maar nasionale ... daar is niks teen etniese kerke in te bring nie...". Weereens, dis min-of-meer waar, maar dis te min waar om heeltemal waar te wees: Die skrywer laat namelik agterweë om daarop te wys dat die eerste gemeente daardie "taalgrens" en skeiding nie geduld het nie en dat Paulus die eerste en die derde hoofstuk van sy brief aan die Korinthiërs wy aan die bestraffing van daardie verdeling tussen Sefas-, Apollos- en Paulus-partye in die Kerk en dat hy in al sy briewe in al sy gemeentes die etniese verdeling tussen Jode-Christene en nie-Joodse Christene met alles in sy vermoë veroordeel. Dink Prof. du Preez dis teologies reg om wat in die Skrif as 'n ondeug 
veroordeel word, aan die Christendom van Suid-Afrika voor te hou as 'n deugdelike ekskuus vir rasse-apartheid in die Kerk?

Dis ook waar natuurlik, dat die Kerk in Duitsland en in Frankryk en in Holland op ' $n$ nasionale basis georganiseer is, maar dis weer nie die hele waarheid nie; die Kerk in geeneen van hierdie lande sal 'n gelowige van ' $n$ ander ras of 'n ander taal- en kultuurgroep toegang tot sy erediens en sy avondmaalstafel weier nie. En as 'n Fransman in die Duitse Kerk wil lidmaat word, sal hy nie deur die Kerk of die staat in Duitsland verbied word om dit te doen nie. Daar is geen sweem van etniese, kultuur- en taaldeling in die Kerk in Europa op die prinsipiële gronde wat in hierdie boek bepleit word nie.

Daar is nog een ,,skriftuurlik-gefundeerde" argument van die skrywer wat nie ongedaag gelaat mag word nie. Dit gaan om die stelling op bls. 103 waar die skrywer met al die gevolge van veralgemening en verwarring van waardes verklaar: „Waar 'n Blanke Christen trou met 'n Nie-Blanke is die resultaat feitlik sonder uitsondering dat die nageslag terugval tot die heidendom ... die gemengde bevolking neig altyd weg van die Christendom." Tensy Prof. du Preez met gewaarmerkte statistieke die ,feitlik sonder uitsondering" en die ,altyd" kan staaf, bly sy stelling veroordeel as 'n onbewysbare en selfs onwaarskynlike veralgemening. Die feitelikheid is namelik dat 'n Blanke Christen en 'n Nie-Blanke Christen uit praktiese oorweginge van christelike verantwoordelikheid teenoor hulle nageslag nie met mekaar trou nie. Sulke huwelike en buite-egtelike verbindinge vind in Suid-Afrika nie plaas binne die Christelike Kerk nie, maar juis daarbuite. Die skrywer sal dus sodanige statistieke nie kan opstel nie. Maar sy veralgemening staan ook veroordeel in die lig van die geskiedenis, wel nie van die huidige Suid-Afrika nie, maar van die vroeë Noord-Afrika. Augustinus, die beroemdste Kerkvader van die Weste was die seun van 'n blanke romeinse offisier en die vrome Berbervrou, Monica. Hy het opsigtelik nie "teruggeval tot die heidendom" nie. Die stelling is derdens een van die menigte nawysbare verwarringe van waardes in hierdie boek: Die skrywer neem sonder meer in sy stelling aan dat die "Nie-Blanke" party ' $n$ heiden is. Bly sy stelling nog waar in die geval waar 'n Blanke Christen met 'n Nie-Blanke Christen trou? Sy verdere verklaring dat die gemengde bevolking altyd wegneig van die Christendom, is 'n ernstige aanklag teen die Kleurling-gemeentes van die Kaap. Kan hy dit staaf? En ten laaste sy stelling weerspreek Paulus se verklaring in I Kor. 7:12-14 veral die laaste vers, ,Want die ongelowige man is geheilig deur die vrou, en die ongelowige vrou is geheilig deur die man; want anders sou julle kinders onrein wees, maar nou is hulle heilig." 
Dit is miskien wel nodig om by die kritiese oorweging van die inhoud net kortliks nog 'n paar van die Germanismes en ander styl-afwykings aan te dui. Op bls. 8 gaan die gewone kerkman uit die woordgebruik en die woordvolgorde nie aflei wat' $n$, uit liefde gevorderde seelsorgerische raadgewing" beteken nie en ook nie wat 'n volk op bls. 122 met sy ,volkstum" verloor nie. Hy gaan op bls. 128 nie weet waarin 'n ,,volkshafte" mens hom van 'n ordinêre mens onderskei nie en wat nou gebeur as daardie mens op bls. 216 en 225 ,heimatloos" raak nie. En die Bantoe ,akademiker" van bls. 198 kan dink dat hy uit oorweginge van diskriminasie nie soos die blanke 'n , akademikus" heet nie. Die leser sal die herhaalde maar steeds germanistiese ,in laaster instansie" moet aanhoor as 'n nuwe geluid in Afrikaans. Waarom moet "Schadenfreude" op bls. 204 verafrikaans word na "skadevreugde" terwyl ons eie "leedvermaak" soveel duideliker en gevoelvoller is? Bedoel die skrywer met „misagting" minagting of veragting en met die ,,mistroue" op bls. 123 gewone wantroue? Of misgis ek my as ek dink dat die ,so-syn" van bls. 60 veel lyk op die So-sein van die Duitse Eksistensialiste? Hier en daar duik sommer hele onverteerde Duitse ontleninge op... die "Geistsein" van die mens op bls. 123 en die nasie-trotse rasbewuste hoogontwikkelde Bantoe wat vol „Leidenschaft" wag op die gebiedskeiding op bls. 138. Dit word bepaald verwarrend wanneer die skrywer onder Duitse invloed praat van 'n „Bantoe jeug in die hande van 'n sewentigtal Blank gerigte sendingsorganisasies" (bls. 172). Die sinsverband dui aan dat die Duitse woordsamestelling sien op sendingorganisasies wat deur Blankes beheer word. Op bls. 146 word die gewone afrikaanse woord, selfsugtigheid, vir Afrikaners verduidelik met die Duitse Selbstlosigkeit in hakies. En netso, op bls. 135 moet die Afrikaner deur "Abwertung” of ,,abwertende Unterscheidung" leer wat die Afrikaanse woordjie, ,geringskat", nou werklik beteken.

Die outeur, volkshafte voorvegter van die volkstumlichkeit van die Bantoe en van die Afrikaner, ,,verkwalik" my dit nie as ek daarop wys dat ,die voleinding stcan nog uit" op bls. 123, na al die onverteerde Germanismes, 'n onbekookte Anglisisme is nie. Mag ek hom origens maan tot versigtigheid met die Engels. Ek het die boek van Jeffreys waaruit hy op bls. 62 met smaak aanhaal, nie gelees nie, maar ek het rede om te vermoed dat die Engelsman ,illusions" geskryf het waar Prof. du Preez „elusions" aanhaal; te meer daar hy onder aan bls. 263 in Afrikaans „elusie” skryf waar die sinsverband „illusie” verwag. Die Afrikaanse sinsbou vaar in hierdie boek al nie beter nie. Op bls. 58 moet ,al die inboorlingstamme het geen deel gehad in die Afrikaner se lot om uit Europa te kom nie" klaarblyklik beteken, „Geeneen van die inboorlingstamme het deel gehad aan die Afrikaner se lot..." En die kursiefgedrukte „Waaruit kom die integrasie voort?" wil seker vra, „Waaruit 
kom die integrasie-beleid voort?". Wat moet die leser op bls. 63 wys word uit hierdie vormlose sin: „Die gevaar hiervan-waar baie in ons dae blind voor is-is dat dit beteken in hoe 'n mate 'n verheerliking en verabsolutering van die Europese mens met sy beskawing." ? Op bls. 105 wil die stelling, „Die Soma-Christou laat die opheffing van die lede van die gemeenskap nie toe nie." seker beteken, "Die Soma-Christou laat die opheffing van die lidmaatskap van die gemeenskap nie toe nie". Teen die middel van bls. 114 verklaar die agtelosige woordkeus selfs dat die Christendom die kultuur van 'n volk skend! Onsuiwere sinsbou wat onsuiwere denke openbaar, loop op bls. 238 uit op, , . . toe die Roomse suster St. Aiden, 'n geneesheer wat haar mediese dienste onselfsugtiglik an die Bantoes ... gelewer het, so afskuwelik opgetree het". Die feitelikheid wil, en so wil waarskynlik Prof. du Preez ook, dat nie Suster Aiden afskuwelik opgetree het nie, maar dat afskuwelik teen haar opgetree is.

Hierdie ,,misagting” van elementêre sinsbou word alleen ge-ewenaar deur die totale veragting van die onbenullige ou kommatjie, 'n minderwaardige lid, weliswaar, in die ry van ons leestekens maar nietemin met 'n onontbeerlike heerlikheid beklee vir helder skryf en helder verstaan.

Helder verstaan word buitendien verhinder deur die vormlike samestelling van die boek. Om al die verwysinge in die betoog saam te vat in 'n bylaag agter in die boek, verplig die leser om voortdurend heen en weer te blaai. Maar het mens nou eenmaal die betrokke verwysing gevind, dan merk jy dat die skrywer 'n splinternuwe gebruik vir hierdie vorm van antekening ontwerp het. In gewone wetenskaplike skrywery dien 'n verklarende aantekening, hetsy onderaan die bladsy hetsy aan die einde van 'n hoofstuk, om die leser te lei na die bronne waaruit die skrywer put. Nie so in die geval van die boek van Prof. du Preez nie. 'n Verklarende aantekening beteken vir hom die geleentheid om met sy tweede wind en in kleindruk sy uitverkore skywe om te skiet: Keet, Marais, Buskes, Visser 't Hooft, die Nêreldraad van Kerke, Amerika en die Engelse.

Naas sinsbou en vormgewing kenmerk 'n oorspronklike manier in die hantering van feite-materiaal hierdie boek. Bls. 36 onderaan verklaar met stelligheid, ,Dit is belangrik om daarop te let dat die eintlike aanraking tussen swart en wit in Suid-Afrika alleen sowat 135 jaar gelede plaasgevind het"--dus teen 1824 . Die voorlaaste paragraaf op die volgende bladsy sê egter, ,Teen 1812 het die burgers langs die Oosgrens begin om van Bantoe arbeid gebruik te maak"-dus teen 1812. As mens nou die drukfout (?) op bls. 39 van 1878 herstel na 1778 dan verklaar die skrywer dat in daardie jaar al Blanke en Bantoe op die Oosgrens ontmoet hetdus nou-al teen 1778 ! Watter een van hierdie geskiedkundig belangrike datums van die eerste ontmoeting tussen Blank en Bantoe moet die leser nou aanvaar? 
Op gesag van Lamott, maar daarom nie minder histories onjuis nie, verklaar die skrywer op bls. 116 dat die Noord-Afrikaanse Kerk van die aardbodem verdwyn het omdat dit die inheemse bevolking nie met die Evangelie aangeroer het nie en beperk gebly het tot kolonies van Europeane met 'n Grieks-Romeinse kultuur. Skrywer is blykbaar onbewus van die ononderbroke bestaan van die Koptiese Kerk tot vandag toe. Hy is ewe-eens onbewus van die ontdekking van 'n hele Christelik-koptiese biblioteek te Nag-Hammadi naby Luxor in 1948, waaruit blyk dat die Kerk in Noord-Afrika wél inheems geword het. As wetenskaplike dogmatikus het hy seker net vergeet van Augustinus se getuienis ten aansien van die inheemsgeworde Kerk in NoordAfrika. As biskop aan die begin van die vyfde eeu van Hippo, die teenswoordige Bône, skryf hierdie Kerkvader 'n brief aan Pous Celestinus (Ep. 29, 2.3.) oor die keuse van 'n biskop vir die gemeente Fussala. Hy beveel by die Pous ene Antonius aan, qui et punica lingua esset instructus. Die Evangelie in Punies vir Puniese gelowiges. So inheems was die Kerk dat die Donatiste selfs punies-sprekend was blykens Augustinus se brief 108,4 aan Macrobius. Hy verklaar met soveel woorde in sy De Haeresibus ad Quodurultum dat in die Kerk van sy tyd punies gepraat word. En in sy preke, vergelyk Sermo 157,4, haal hy selfs 'n puniese spreekwoord aan en Sermo 288 bevat niks minder nie as 'n puniese woordspeling! Van die oudste vertalinge van die Nuwe Testament bestaan in Sahidies en Bohairies, twee Noord-Afrikaanse dialekte. Hulle stam uit die vroeë vierde eeu. Nee, die oorsaak van die verdwyning van die Kerk in Noord-Afrika lê, soos elke leser weet, nie in die feit dat dit inheems geword het of nie inheems geword het nie, maar in die uitdelgingsgolf van die Mohammedanisme aan die begin van die Middeleeue.

Ook ten aansien van die meer resente geskiedenis vertoon die werk feitelike misvattinge. Op blse. 5 en 231 verklaar hy dat die Bekennende Kirche van Duitsland weens inwendige verdeeldheid nie die oë ge-open het vir die gruwels van die Nazisme nie; hy noem as verdeeldhede van hierdie Kerk, die konfessionele rigting, die Barthiaanse rigting en die nuwe Liberalisme onder Bultmann. Vereers al fouteer die skrywer met die naam „Bekennende Kirche”. Die geval is namelik dat sedert die begin van die dertiger jare die „Glaubensbewegung Deutsche Christen", die Christelik-nasionale deel van die Kerk en slaafse navolgers van die Nazi-regering se beleid van rasse-skeiding in Kerk en maatskappy, daarin geslaag het om stelselmatig die mag in meeste van die "Landeskirche” in hande te kry. Reeds in September 1933 vorm die Christus-belydende deel van die Kerk ' $n$ weerstandsgroep teen die introduksie in die Kerk van die sogenaamde "Arierparagraphen" waarvolgens Jode nie tot dieselfde Kerk as Duitsers mag behoort nie. In daardie maand en in daardie 
jaar ontstaan die weerstandgroep die „Pfarrernotbund” en uit hierdie laasgenoemde het die „Bekennende Kirche” gegroei. En hierdie „Bekennende Kirche" met martelare soos Niemöller, Dietrich Bonhoeffer, Arthur Frey en Karl Barth hou, in weerwil van vervolging, tronkstraf, konsentrasiekampe en verguising vol om die Duitse volk tydig en ontydig te waarsku teen die gevaarlike weg wat hy volg. Om te ontkom aan die rasse-ideologiese leiding van die Deutsche Christen wat die Kerklike organisasie beheers het, stig die Bekennende Kirche in 1934 sy eie ,,Vorläufige Kirchenleitung". Dis hierdie Bekennende Kirche wat protesteer teen die „Nürnberger Gesetze" van die 15de September 1935 wat die vernaamste burgerregte aan die Jode onttrek en huwelike tussen Jode en Nie-Jode verbied met die "Gesetz zum Schutz des deutschen Blutes und der deutschen Ehre". Dis hierdie Kerk wat protesteer teen die wet van die 4de Julie 1939, die sogenaamde „Reichsbürgergesetz” wat algehele rasse-afsondering van Jode in Duitsland be-oog. Maar dis hierdie „Bekennende Kirche" wat in 1937 die moedige Barmen-Erklarung opstel waarin die sigbare aard van die ondeelbare Christelike Kerk gestel word teenoor die duitse manie om rasse-deling in die Kerk aan te bring. Dis hierdie Kerk wat, met lewensgevaar vir sy lede, waardig maar luid protesteer teen die Wet van die 1ste September 1941, die „Polizeiverordnung über die Kennzeichnung der Juden” waarvolgens ook „Mischlinge 1 Grades”, d.w.s. kinders uit die huwelik tussen 'n Jood en 'n Duitser, die geelster moes dra. En hierdie Kerk het die lewe van sy lede gewaag toe in 1944 die uitdelgingsaksie teen die Joodse volk ook uitgebrei is na die sogenaamde „,Mischlinge”. Om die stelselmatige uitroeiing en uitbuiting van Jode te voorkom, het sedert 1938 binne die Bekennende Kirche tot standgekom die beroemde Büro Grüber onder leiding van Pfarrer Grüber van Berlyn. Hierdie bureau het letterlik duisende Jode van vernietiging gered, selfs toe sy liefdesaksie en sy Evangelieprediking aan die Jode deur „offisiële" Christene van Duitse Christelik-nasionale stempel veroordeel is as „Eingangstor fremden Blutes in unseren Volkskörper" en as 'n ,schwere Gefähr für unser Volkstum”, ja „Volkstum”!

Verre van onenigheid tussen Bekennende Kirche en Barth, het Barth en Arthur Frey juis om hulle eenheid met die Bekennende Kirche en sy verset teen die rasse-deling van die Owerheid, onder bedreiging van vervolging uit Duitsland gevlug.

Hoe Prof. du Preez by Bultmann uitkom weet ek nie. Bultmann is 'n eenvoudige Nutestamenticus wat op 'n bepaalde eksegetiese teorie werk, wat wel heelparty vak-ondersteuning geniet, maar hy is nie en probeer ook nie om die leier van 'n party binne die Kerk te wees nie. Om die kritiese leser die geleentheid te gee om die skrywer se stellinge oor die Bekennende Kirche aan die waarheid te toets, verwys ek hom na Kirchliches Jahrbuch 1953, Bertelsmann Verlag, Gütersloh. 1954, S.295; 
ARThUr Frey, Kampf der Evangelischen Kirche im Deutschland. Die Barmen Erklärung. Bekenntnisschriften und Kirchenordnungen der nach Gottes Wort Reformierten Kirche. Zollikon Verlag, Zurich, 1938.

Asof dit nie genoeg is om die Bekennende Kirche te verongelyk nie, volg daar op bls. 210 die volgende uitbreiding van die beskuldiging: „Dit is hier juis waar die Wêreldraad van Kerke in sy roeping gefaal het. Die Europese Kerk en Teologie het op die kritieke tyd gefaal in sy roeping deurdat hy verkoppel geraak het aan die Nasionaal-Sosialisme en Gods Woord nie kon spreek teenoor Jodevervolging en Staatsabsolutisme nie". Die teendeel is waar. Prof. du Preez moet net die voor die oorlog verskene boek van die Dean of Chichester lees, The Struggle for Religious Freedom in Germany, of Adolph Keller se Vyf Minuten voor Twaalf. En om die Wêreldraad met die Nazisme te koppel is eenvoudig van alle waarheid ontbloot. Buitendien die Wêreldraad het eers in 1946 te Amsterdam tot stand gekom, toe die Nazisme dood en begrawe was.

En hoor op bls. 131 die onterende beskuldiging teen Nederland: „Wat die Indonesiërs teen in opstand gekom het, was ... die uitbuiting in eie belang deur 'n buitelandse koloniale moontheid". Mens sou aanneem dat die skrywer so-iets van die allerweë erkende modelkolonie van Nederland in onnadenkendheid geskryf het. Die beskuldiging rus nie op feite nie maar op die skrywer se ingenomenheid met apartheid want op bls. 246 praat hy selfs met lof van die apartheidsmaatreëls van niemand minder as Soekarno nie: „In Europese lande soos Holland waar die kleurgevoel nie so sterk is nie, kry mens baie halfbloede sodat die teenswoordige Indonesiese regering self blykbaar bewus is van die gevare van vermenging en hulle Javaanse studente wat in Holland gaan studeer streng belet om hulle nie met Hollandse meisies te verloof nie".

Mens begin die gang van die skrywer se gedagtes te peil, wanneer hy in weerwil van sy felle afwysing hier-en-daar van ,rasse-demonie" in navolging van sy groot informant, ene Gedat, Kwane Nkrumah begin prys: „Kwane Nkrumah kan volgens Gedat waarlik 'n leier van sy volk genoem word omdat hy een van die ,volkstümlichsten' persoonlikhede van die Weskus van Afrika is en geroem word nie alleen om sy verbasende welsprekendheid wat die massas boei en meesleur nie maar ook om sy onselfsugtigheid (Selbstlosigkeit) en sy heelhartige oorgawe aan die nasionale saak". Dis die Nkrumah wat hom deur sy volgelinge as Messias laat vereer. Dis duidelik, wie waar ter wêreld ook-al 'n voorstander is van rasse-apartheid, ontvang om die rede van die skrywer lof; en wie rasseapartheid kritiseer, ontvang om die rede sy afkeuring. Die Wêreldraad van Kerke is vir hom om die rede op bls. 213 'n bondgenoot van die Kommunisme, 'n handlanger van Amerikaanse kapitaal, „'n gevaarlike saaier van wantroue" en 'n godsdienstige klankbord van die V.V.O., 'n organisasie wat wel nog 'n funksie het as hy hom bekeer, die waarheid 
leer en die ekumeniese kerk reg inlig, d.w.s. die verdeling van die een heilige algemene Christelike Kerk op rassegronde billik.

Eintlik moes mens volstaan met bogenoemde proewe van die skrywer se interpretasie van huidige en vergange geskiedenis. Ek ervaar ook 'n sekere huiwering om sekere stellinge van die boek in 'n openbare kritiek met die historiese feitelikheid van die afgelope paar jare in ons land reg te stel; dit kan lyk of mens vuil wasgoed in die openbaar was. Ek beperk my dus tot nog net twee regstellinge ter wille van die waarheid voor die oë van die buiteland en van die binneland. Die skrywer verwys dikwels na Prof. Otto Weber asof laasgenoemde die apartheidspolitiek sou steun. Tog het dieselfde Prof. Weber net voor die verskyning van hierdie boek protes ingedien by ons regering teen die skepping van aparte universiteite. Hierdie klaarblyklike teenspraak noop my om ter wille van die eer van Prof. Weber, sodat hy nie verdink word van uit twee monde te spreek nie, aan Prof. du Preez voor te stel dat die vraag direk aan Weber gestel word of hy die beleid van totale apartheid in die Unie goedkeur en dat sy antwoord onveranderd gepubliseer word in ons openbare pers. Verder, in sy teregwysing aan Ds. J. J. Buskes op bls. 243, verklaar skrywer dat die benaming ,skepsel" vir die naturelle in ons land 'n dood-natuurlike en selfs liefderyke inhoud het: „Die woord ,skepsels' druk in Afrikaans nie minderwaardigheid uit nie maar juis tere simpatie, 'n gevoel van deernis met die lot van ' $n$ medemens. As 'n skamel geklede Naturel natgereën het, sou ons sê: Bring die arme skepsel tog in om hom eers warm te maak by die vuur". Om die proef op die som te plaas, sal Prof. du Preez omgee dat iemand in Suid-Afrika na hom verwys as 'n arme skepsel?

Ter wille van die waarheid moet binne- en buiteland ook weet dat die voorstelling wat die skrywer van Prof. B. B. Keet en Prof. Ben Marais gee, van alle grond ontbloot is. Wie Prof. Keet ken, weet dat dit nie alleen onwaar is nie maar ook oneerbiedig om van hierdie enigste nog oorlewende vertaler van die Bybel in Afrikaans te sê dat hy ,,smalend praat" (bls. 95). Is die skrywer op die laaste reël van bls. 255 werklik besig om Prof. Marais "huigelary” aan te vryf, of lei sy onduidelike sinsbou mens tot hierdie gevolgtrekking? Sonder om die allerweë etkende integriteit van Prof. Marais te verdedig, sal 'n ontleding van die argument wat die skrywer hier en op bls. 5 en verder voer, die beste teenbewys lewer van sy beweringe teen hierdie hoogstaande twee manne. Hulle het naamlik op 'n samespreking in Stellenbosch en ook in geskrifte verklaar dat daar geen skriftuurlike gronde vir die deurvoering van rasseskeiding in die Kerk bestaan nie; dat, inteendeel, die Skrif die eenheid van die Kerk eis in weerwil van die verskil tussen rasse; hulle verwag egter geen rewolusionêre omsetting van die konkrete historiese omstandighede wat op hierdie oomblik in die Kerk in Suid-Afrika bestaan nie. Maar hulle verwerp ook op hierdie oomblik die onskriftuurlike voor- 
stelling dat Nie-Blankes op grond van hul kleur uit die „Blanke Kerk" geweer moet word. Hulle het geen beswaar teen afsonderlike samekomste van Naturelle nie uit oorweginge van taalverskil; maar eksklusiewe Blanke Kerke waar 'n Nie-Blanke gelowige nie eers mag inkom om saam te aanbid nie, is onder alle historiese omstandighede, ook die huidige, uit elke Bybelse en teologiese benadering, onverdedigbaar. En dat die drie Afrikaanse Kerke vandag nie toelaat dat 'n Nie-Blanke aan hul eredienste deelneem nie, is geen geheim nie. Prof. du Preez noem dit elders in sy boek self. Daarteenoor het Prof. du Preez in sy rapport voor die Transvaalse Sinode in 1951 verklaar dat skeiding in die Kerk op grond van rasse-verskille in die lig van die Skrif nie alleen toelaatbaar is nie maar selfs verpligtend. Trouens dis ook die tema van 'n werkie van sy hand met die naam van, Die Skriftuurlike grondslag van Apartheid. Die ekklesiologie wat hy in hierdie nuwe boek huldig, sit so vol selfweersprekinge dat ' $n$ aparte paragraaf vir die aanwysing daarvan nodig sal wees. Vir die argument van die oomblik is dit egter van belang om daarop te let dat hy min-of-meer afsien van sy voormalige verdediging van apartheid in die Kerk op Skriftuurlike grondslag en dat hy nou terugval op presies dieselfde praktiese gronde vir sy verdediging van apartheid in die Kerk. Tog verwyt hy Proff. Marais en Keet dat hulle apartheid in die Kerk op praktiese gronde en nie skriftuurlike gronde nie, wil duld. Hy sê op bls. 83, ,Bowendien ly hulle (die Nie-Blankes) gedurig onreg deurdat die taal wat gebruik word in 'n gemengde kerk, die siel van die Bantoe nie aanspreek nie". Vanaf bls. 111 tot bls. 120 doen hy trouens niks anders nie as om praktiese gronde aan te voer vir rasseskeiding in die Kerk nie.

Trouens as mens die Sinodale-besluit van 1857 neem, wat Prof. du Preez iewers ook aanhaal as maatstaf van die gedragslyn van sy Kerk, dan is dit nie Proff. Keet en Marais wat daarvan afwyk nie, maar juis Prof. du Preez. Op grond van die versoek van die gemeente van Stockenström, het die Sinode namelik besluit dat hoewel dit wenslik en skrifmatig is dat die Nagmaal aan Blankes en Nie-Blankes gesamentlik bedien word soos in die verlede, daar tog weens die swakheid van sommiges (t.w. sommige Blankes) aparte bedieninge ingestel mag word waar Kerkrade so besluit. Sê Prof. Keet en Prof. Marais nie nog al die tyd presies dieselfde nie? Daarom doen die skrywer se morele verontwaardiging oor die volgende feitelik juiste verklaringe van Prof. Keet so vreemd aan: „The plain intent of apartheid ... is progressively to diminish all points of contact with the Coloured races, even to the extent of closing the church doors of the European community to them." (bls. 239, vgl. ook bls. 201). Waarom neem hy Prof. Keet kwalik vir sy gegronde en christelike verklaring dat apartheid in die Kerk sal bly totdat daar ' $n$ verandering van die hart by die Blankes plaasgevind het? Die sinode van 1857 sê 
in ander terme tog presies dieselfde (vgl. bls. 256). Op bls. 250 meen hy in ' $n$ verklaring van Prof. Keet ' $n$ selfweerspreking te vind-dit is insidenteel geen selfweerspreking nie-maar as mens al Prof. du Preez se selfweersprekinge in hierdie boek moes stel, sou daar 'n splinternuwe boek uit te voorskyn kom. 'n Paar van die opvallendstes gaan ek hier egter tog aanwys.

Tot vervelens toe herhaal Prof. du Preez in sy ywer om apartheid te verdedig, dat die Blanke en die Nie-Blanke weerkerig geen geneigdheid vertoon om te vermeng nie. Ek verwys o.a. na bls. 45, 70, 71, 73, 79, 166. Op bls. 72 egter laat hy van daardie weerkerige ongeneëntheid niks oorbly nie wanneer hy verklaar: „Ons volk is dus van die vroegste tye weerhou van rassevermenging deur wetgewing..." Een van twee kan reg wees maar nie altwee nie: Of ons het ' $n$ weerkerige afkeer van bloedvermenging soos Proff. Keet en Marais verklaar en soos Prof. du Preez dit in onbewaakte oomblikke toegee, of ons het daardie natuurlike afkeer van die vroegste tye nie gehad nie en moes deur w'etgewing daarvan weerhou word. Die buitelander wat tog al voortdurend versoek word om stil te bly oor ons rassepolitiek omdat hy die probleme van Suid-Afrika nie kan verstaan nie, moet voor so 'n redenering toegee dat hy ons logika ook nie verstaan nie. As die kleurgroepe weersyds en weerkerig ongeneë is om te vermeng, waarom moet hulle dan met wetgewing gedwing word om nie te vermeng nie?

Op bls. 48 en 90 veroordeel die skrywer nasionalisme, d.w.s. swart nasionalisme, in die Bantoe-kerke en hy bestempel dit as ' $n$ poging om „,kultuurgoedere met besondere oogmerke uit die verlede te laat herleef 'n voorbeeld waarvan die Mau-Mau is". Nou toe nou. Die hele opset van hierdie boek is dan om „eiesoortige ontwikkeling”, die herstel van die ou Bantoe-kultuur te bepleit! Die skrywer is 'n voorstaander van aparte ontwikkeling van 'n Blanke christelike nasionalisme en wil graag die swartman dieselfde christelik-nasionale vreugdes verskaf. Dis tenminste wat ek onderaan bls. 55 en trouens op talle ander plekke in hierdie boek lees, b.v. ,,Hiermee word klem gelê op die ontwikkeling wat noodsaaklik is vir die Nie-Blankes en dat dit (nl. apartheid) be-oog om hulle te help tot kulturele selfstandigheid."

Op dieselfde bls. 57 lees mens dat „Volkstum und Rasse" nie te verklaar is uit kleur en rassegevoel nie; en met dieselfde asem onderskryf die outeur die Tomlinson-verslag se bevinding dat rassegevoel ten grondslag lê aan die rassebeleid in Suid-Afrika!

Op bls. 68 lei hy ons tot die slotsom dat in die Skrif rasverskil geheel op die agtergrond tree. Maar drie bladsye verder verklaar hy gesagvol, „Maar die Blanke en Nie-Blanke rasse lê om verskillende redes so ver uitmekaar dat hulle (al sê God ook dat man en vrou een vlees sal wees) 
nie een vlees kan word nie". Die rasverskil skyn nou sterker te wees as God se Woord, as die Skrif!

Bls. 252 wil met verontwaardiging weet waarom soveel mense soveel beswaar maak teen die fameuse „Kerkklousule” van Dr. Verwoerd terwyl die Smuts-regering al in 1937 en 1945 dergelike kontrole-maatreëls ingestel het. Sal die arme buitelandse Teoloë wat in hierdie paragraaf tereggewys word, dan nie kan vra waarom, gesien dat die Wet al bestaan het, Dr. Verwoerd dit weer moes maak nie?

Op talle plekke in hierdie boek en een keer selfs met die gesag van Mnr. C. W. Prinsloo, wys die skrywer aan hoe gunstig die gevoel tussen Blank en Swart teenoor mekaar geword het sedert die instelling van Apartheid. Tog haal hy met instemming op bls. 90 Jacottet aan: "Complete separation between European and Bantu churches is quite imperative because of the general feeling of the European towards the Bantu". Insidenteel is Jacottet reg, en ook Prof. Keet en ook die redegewing van die Sinode van 1857. Maar wat bly daar nou van konsekwensie oor in die redenering van Prof. du Preez?

Op bls. 131 word verklaar dat die Nederlanders koloniale uitbuiters in Indonesië was. Op bls. 132 onderskryf die outeur Bavinck se woorde, „Onze vaderen waren geen rovers en avonturiers ..."!

Deurgaans bepleit die skrywer die skepping van selfstandige Bantoestans in Suid-Afrika ten einde die Naturelle die geleentheid te gee om vry van Blanke-kompetisie eiesoortig te ontwikkel. En tog, op bls. 205 betig hy die buitelanders om ,hulle verstandelose toejuiging van die selfstandigwording van Afrikaanse gebiede"! As domper op hulle verstandelose vreugde wys hy dan op die selfvergoddeliking van Ghana, die Ghana van die Nkrumah wat hy netnou maar 'n ,selbstlose nationale Führer" van sy volk genoem het!

Omdat die tyd kort is--hoe kort sê die skrywer nie, hoewel hy op bls. 160 beloof en vanaf bls. 204 poog om dit te presiseer-moet eiesoortige ontwikkeling van die Naturel in sy eie gebied daarom volgens hom sonder versuim geimplementeer word, want apartheid is die enigste voorwaarde vir die behoud van Swart en Wit in ons land. Asof hy heeltemal van hierdie eis vergeet het, verklaar hy goedsmoeds op bls. 132 dat die Naturel nog nie ryp is vir selfstandigheid nie en op bls. 141 dat hulle hulself nie kan bestuur nie en op bls. 212 twyfel hy of die Naturel ooit die dinge sal kan doen wat die Europeër doen, met ander woorde tot volledige selfstandigheid kan ontwikkel! In hierdie verband moet ook gewys word op die herhaalde aanspraak in die boek dat die Blanke die Godgewilde voog van die Naturel in Suid-Afrika is. Dit mag so wees. Maar watter soort voog is dit wat sy nog onvolwasse en ongerypte sorg aansê om elders te gaan eiesoortig ontwikkel en hom bowendien verseker dat die kultuur en geestesgoed van die voog vir sy jong sisteem gif is. 
Prof. du Preez kan nie genoeg aanwys hoe sleg die Westerse kultuur in die algemeen en vir die Naturel in die besonder is nie. Dis bepaald verwarrend vir die Westerling en ook beskamend. Maar hy moet wel met verbystering op bls. 255 lees dat die oorsaak van aparte rasse-kerke by ons nie die sondige onwilligheid van mense is om saam te aanbid nie. En tog het Prof. du Preez die waarheid van Jacottet se stelling onderskryf dat aparte kerke noodsaaklik is weens die houding van die Blanke teenoor die Naturel en dat Lamotte reg het wanneer hy sê, ,the Church must lose its European form and colour... because of the general feeling of the European towards the Bantu" (114). Prof. du Preez haal ook met instemming aan die besluit van die sinode van 1857 dat aparte bediening toegelaat word weens die swakheid van sommige (Blankes). Op bls. 208 verklaar hy self dat minagting en weersin teenoor die Naturel by die Blanke bestaan! Is dit nie selfweerspreking nie?

Niemand kan beswaar hê daarteen dat die skrywer 'n buitengewone bewondering vir die Bantoe-kultuur openbaar nie. Dit word weliswaar 'n bietjie kras as hy in sy ywer daarvoor verklaar dat die Bantoe ,'n beter begrip van vaderskap as die Westerling het, omdat die stamhoof die Vader is". Moontlik kan die Westerling verbeter deur ook vir hom 'n stamhoof deur die regering te laat aanwys en dit dan vader te noem. Maar vaderskap in die algemeen? Die Tomlinson-verslag meld iewers dat 60 persent geboortes onder Naturelle in die stede buite-egtelik is. „Hulle weet ook meer van broederskap as ons", vervolg die skrywer. Stam-oorloë en die reëlmatige biergevegte dan?

„Om dit alles te verloor in navolging van die Westerse kultuur, sou beteken om te verval tot egoisme en selfsug" (bls. 60 en 61). Tot hiertoe kan mens verdra wat die skrywer oor jou Westerse erfenis te sê het en jy kan selfs verdra dat hy impliseer dat dit die sinoniem van egoisme en selfsug is. Wat egter nie geduld kan word nie omdat dit histories foutief is en omdat dit ' $n$ onbewimpelde belediging is vir ons Westerse erfgoed, is die volgende uitsprake wat ek heelhuids met bladsy-veruysing aanhaal. Op bls. 63 verklaar hy dat sedert die Renaissance ons Westerse Kultuur gesekulariseer is, sodat dit vandag meer Grieks en gehelleniseerd is as Christelik. Onthou, Luther, Calvyn en die Kerkhervorming het almal sedert die Renaissance gekom. En dan oordeel hy dat Rousseau reg was toe hy gesê het dat ons ontslae moet raak van die ongeregtighede wat ons ,,beskawing" noem en moet teruggaan na 'n soort paradys-toestand. Nou-ja, Phillips en Dr. van der Kemp het ook soos Rousseau oor die saak gedink. Met hulle sienswyse strook ook Prof. du Preez se verklaring op bls. 75 dat dit ,'n verloëning van die diepste wese van die Naturel sal wees as hy die Westerse kultuur toe-eien waarin daar menige twyfelagtige faktor is". En met Dr. Eiselen as outoriteit oordeel hy op bls. 93 dat die „kultuur-selfvoldane Westerling” met sy „hooghartige self-oorskatting van die Westerse 
beskawing" geen beter geestesgoed het as die Naturel nie. En die Naturel moet daarom op bls. 98 ,nie kom tot verslawing aan die Westerse denkvorme nie". Dis 'n ,überfremdende" soort dagga hierdie wat sy eiesoortige ,,volkstümlichkeit” sal rinneweer. „As die Bantoe daarom Christen word", bls. 114, „moet hy nie verwesters word nie... mens moet beslis oppas vir die Westerse of Engelse kultuurgodsdiens". Dit gaan my al of ek Kroetsjef hoor op bls. 118: „Die Westerse beskawing is... indiwidualisme, imperialisme, materialisme, industrialisasie, modernisasie en ultra-nasionalisme. Die kapitalistiese Westerse kultuur is nie meer 'n voordeel vir die Christendom nie maar 'n las".

Soos Rousseau, bedien die skrywer hom graag van effens oordrywende werkwoorde en naamwoorde. Hy verklaar op bls. 124 dat Oosterse mense „beslis nie bevoordeel word deur' $n$ afpersing van die Westerse op hul lewe nie". Met Dr. Verwoerd kwalifiseer hy Westerse lewensvorme as ,aangeplakte" beskawing by die Naturel. Op bls. 200 staan die Naturel onder gevaar om ,oorweldig te word" deur die Westerse lewenswyse sodat hulle as't ware tot hul skade moet oorneem wat die Weste op hul afforseer". Skrywer vind op bls. 255 in die Bybel ,geen reg vir die opdring van Westerse tale aan die Christene uit ander taal- en kultuurgroepe" nie. In die ander voorbeelde waarmee ek hierdie uit die boek sou kon verveelvuldig, bedien hy hom graag van die woordjie ,afdwing" en sinonieme. Veral die Weste en Prof. Keet besondig hulle aan hierdie dwinglandy. Nou is behalwe die kultuurdefaitisme en die growwe veroordeling van al wat Westers is, 'n opvallende kenmerk van hierdie passages dat die beskuldigdes nie eenkeer bewysbaar dwang in reële of oordragtelike sin bepleit om die Naturel te verwesters nie. Maar juis Prof. du Preez bepleit 'n sisteem van wetlike en politieke en kerklike dwang om hom te dwing om nie te verwesters nie, en ergste, om hom met dwang van die geweld van die wet uit die gemeenskap van die heiliges in die één heilige algemene Christelike Kerk te hou.

Prof. du Preez redeneer nie in hierdie boek nie, hy stry. Met vaardigheid gebruik hy kragwoorde om te suggereer dat sy teenstanders iet sê wat hulle in werklikheid nooit gesê het nie. Teenoor Proff. Marais en Keet en die Wêreldraad se argument dat 'n Kerk nie kleur-eksklusief kan wees nie, stel hy dat sodoende ,,anderstalige volksgroepe geforseer word om in dieselfde erediens saam met andere te wees" (bls. 109), en ,dit sou 'n onreg aan die Nie-Blankes beteken ... waar hulle gedwing word om in 'n vreemde taal bearbei te word" (111). Ek herhaal, nie een van hierdie persone of instansies het ooit forsering en dwang bepleit nie, maar alleen uryheid. $\mathrm{Na}$ sy "Skrif-ondersoek" kom skrywer op bls. 68 tot die slotsom: „Blykbaar laat die Skrif dit (huwelike tussen verskillende rasse) aan die normale volks- en rassegevoel oor om sy rol te speel by die keuse van 'n lewensmaat sonder 'n forsering van die 
ras in die een of ander rigting". Wil hy daarmee te kenne gee dat die teenstanders van die Apartheidsbeleid ipso facto en onskriftuurlik en met geweld gemengde huwelike tot stand wil bring? Maar soos meermale die geval in stryery, stry die stryer hom naderhand vas; twee bladsye verder korrigeer hy sy Skriftuurlike gevolgtrekking en verklaar, ,Maar hiermee stel mens jou op die wisselvallige standaard van subjektiewe liefdesverklaring..." Afgesien van die selfu'eerspreking moet mens in alle erns vra of enige liefdesverklaring ooit anders as „subjektief" is. Hoe lyk 'n "objektiewe" liefdesverklaring? En waarom is die vryheid in keuse wat die Skrif so flussies aanbeveel het, nou skielik 'n „wisselvallige" standaard? Maar dis nog nie klaar nie. Daardie Skriftuurlik vry en verkore lewensmaat uit die ander ras bestempel hy nou op bls. 71 as 'n „,bywyf": „Uit die gesigspunt van gelykwaardigheid van mense is dit onduldbaar dat die anderrassige as bywyf sou uitgebuit word". Is elke vrou wat van haar man in kleur verskil omrede van die kleurverskil nie sy wettige vrou nie maar sy bywyf? Was Mooi Monica van de Kust, die moeder van Simon van der Stel, sy vader se „bywyf" omdat sy 'n Indiese vrou uit Mauritius was? Volgens Num. 12 het God Aaron en Mirjam verskriklik wit gemaak, melaats-wit, omdat hulle Moses omrede van sy anderskleurige vrou verag het.

Niemand, nie Prof. Keet nie, nie Prof. Marais nie, nie die Wêreldraad of enige kritikus van apartheid ontsê aan die Naturel die reg om sy eie-aard te handhaaf as hy wil nie. Maar dis juis wat Prof. du Preez beweer met 'n uitspraak soos op bls. 96: „Onder die omstandighede mag aan die Blanke sowel as aan die Nie-Blanke die reg nie ontsê word om homself te verweer teen "oorvreemding" nie. En die soek na die eenheid van die Kerk soos die Here ons dit beveel, noem hy ,'n sogenaamde demonstrasie van kerklike eenheid" en weer ,'n geforseerde gesamentlike aanbidding". Hierdie soort redenering is so onvrugbaar as wat dit bekend is in SuidAfrika. Elkeen wat apartheid ooit teengestaan het in ons land, ken die onontwykbare teen-argument van die apartis, "Jy wil natuurlik hê jou dogter moet met 'n kaffer trou!' Die skrywer se stelling lei tot die ongegronde slotsom dat wie apartheid teenstaan, vanselfsprekend rassevermenging voorstaan en huwelike tussen Swart en Wit wil ,forseer".

Die boek krioel van foutiewe argumentering. Uit die dosyne wat ek aangeteken het, noem ek ter illustrasie net 'n paar. In sy verdediging van rasse-apartheid voor die buiteland sê die skrywer dat apartheid nie net in Suid-Afrika bestaan nie want ook in Europa is daar Latyne, Germane en Slawe (bls. 58). Natuurlik is daar. Maar die bestaan van hierdie en meer ,rasse"-soorte in Europa bewys mos nie dat Europa ook 'n apartheidsbeleid volg nie. Inteendeel: Geen wet, kerk of instelling differensieër, diskrimineer of skei tussen daardie groepe nie. Om sy rasse-soorte en die noodsaak van skeiding tussen daardie soorte te illustreer, wend hy 
hom tot die vrugtewinkel: ,daar is geen vrugte in die algemeen nie maar net appels, pere, piesangs, ens. en so is daar ook geen abstrakte mensheid nie". (bls. 244). 'n Totaal verwronge parallel. In die eerste plek, natuurlik is daar so-iets as vrugte in die algemeen, omdat "vrugte" netso 'n versamelnaam is as die woord „soogdier". Dan, binne die vrugteryk is daar verskillende soorte vrugte, appels en pere en piesangs netsoos daar binne die ryk van die lewende wesens mense, perde en poue is. Natuurlik is daar 'n wesentlike onderskeid tussen perde en mense en poue netsoos daar 'n wesentlike onderskeid is tussen appels en pere en piesangs. Maar in die appelryk self is daar verskillende soorte appels wat in kleur, vorm en prys van mekaar verskil maar nie in wese nie, netsoos daar mense is wat in kleur, taal en opinie van mekaar verskil maar almal van dieselfde wese, van dieselfde mens is, soos die Apostel in Hndl. 17:26 sê.

Met al die gesag van al sy segsmanne verklaar hy op bls. 93: „Europese Teoloë is in die hoogste mate eenstemmig daaroor dat denasionalisering geen eis van die Christendom is nie". Maar seker; trouens ook alle Suid-Afrikaanse Teoloë sal dit eens wees dat denasionalisering nie die taak van die Kerk is nie. Alleen, die Kerk het dit nog nooit en nêrens as sy taak beskou nie. Buitendien, alle Europese Teoloë, soos meeste Suid-Afrikaanse Teoloë sal dit ewe-eens in hoogste mate eens wees dat nasionalisering of eiesoortige ontwikkeling of rasse-skeiding in die Kerk ook nie die taak van die Kerk is nie.

Christus bid in Joh. 17:20-23 dat alle gelowiges één sal wees. Die Wêreldraad en die ekumeniese strewe van elke verantwoordelike Christen rus op hierdie Christus-gewilde eenheid van alle gelowiges. Prof. du Preez staan op die standpunt dat 'n Nie-Blanke nie in die „Blanke Kerk” mag kom nie. Hy verantwoord hom voor sy lesers deur die begrip ,eenheid van die gelowiges" om te ruil vir ,eenheid van alle mense”. (bls. 119, 124 en 125). en hierdie "kosmopolitiese eenheidsbegrip" dan tot op die grond af te takel. En met reg ook; alleen, nie die Wêreldraad en nie Prof. Marais of Prof. Keet eis so 'n ,,eenheid van alle mense" nie maar wel, en in gehoorsaamheid aan Christus, die eenheid van alle gelowiges waarvolgens die één heilige algemene Kerk nie die reg het om sy deure te sluit vir ' $\mathrm{n}$ medegelowige op grond van sy anderskleurigheid nie.

Hierdie vermenging van ongelyksoortighede kom meermale by die skrywer voor. Op bls. 136 protesteer hy nog een strook deur teen die sigbare eenheid van alle gelowiges deur gemengde stedelike woonbuurtes te verdoem!

Die kritiek het hom beperk tot algemene aanwysinge van denkfoute en die spesifieke naproef van die outeur se gebruik van die Bybel. In geen van beide kategorieë was dit moontlik om selfs by benadering al die misvattinge in die werk aan te wys nie. Die gemiddelde kerkman en teoloog wat hom aan die kritiek van hierdie werk waag, kan ook nie met 
gesag praat oor die politieke en ekonomiese beskouinge van die outeur nie; en die grootste deel van die boek bestaan uit politieke en ekonomiese voorligting. Die gegewens daarvoor lê buite die gebied van die kerkman en teoloog en is klaarblyklik, netsoos al die foto-illustrasies, afkomstig van die Staats-inligtingsdiens. Oor die korrektheid van hierdie gegewens kan die politiek-onkundige moeilik oordeel. Hier-en-daar sou hy wel 'n vraagteken plaas agter sommige te bonte gevolgtrekkinge wat die skrywer op grond van daardie inligting maak. Sy beeld byvoorbeeld van die ekonomiese uitvoerbaarheid van die beleid van algehele apartheid: Die Tomlinsonverslag het in 1951 verklaar dat 'n minimum van $£ 104$ milj. in die daaropvolgende 10 jaar uitgelê moet word aan die ontwikkeling van die Bantoe-reserwes. Dr. Diederichs het gereken dat $£ 600$ milj. nodig sal wees en 'n bekwame ekonoom het bereken dat dit tenminste $£ 2,400$ milj. sou kos. In elk geval is 8 van die 10 jaar al verby en na die beste van my wete is sover $£ 2 \frac{1}{2} \mathrm{milj}$. vir die doel aangewend.

Behalwe die moeilikheid dat hierdie werk in weerwil van sy opset en inleiding nie 'n teologiese werk is nie, is dit vanweë die denkwyse van die skrywer nie maklik te kritiseer nie. Hy redeneer naamlik in absolute teenstellinge. Omdat Marais, Keet e.a. apartheid as beleid kritiseer, is hulle ,dus" vanselfsprekend voorstanders van algehele integrasie en wil hulle die Naturel ,forseer" om sy eie identiteit prys te gee. Die persoon wat daarom die skrywer se skriftuurlike interpretasie van die huwelik kritiseer, staan in die kans om deur hom en gelykdenkendes voorgestel te word as 'n voorstander van bloedvermenging. Wie sy mensbeeld in twyfel trek, kan verwag om beskuldig te word dat hy sosiale gelykstelling bevorder en wie sy interpretasie van die Skriftuurlike leer oor die Kerk weerlê kan soos die Wêreldraad voorgestel word as 'n vyand van die Blanke Christendom in Suid-Afrika!

Dis verder moeilik om die werk te kritiseer omdat dit kragtens sy aanloop, en opset 'n wetenskaplike werk wil wees en dit nie is nie. Die skrywer verwyt Prof. Marais byvoorbeeld sy gebruik van buitelandse outoriteite. Prof. Marais noem minstens in sy werk by elke opinie die naam van sy informant. Die skrywer beperk hom tot sulke algemene aanduidinge van sy informante as ,die meerderheid van die buitelandse teoloë" of „feitlik alle Europese teoloë”. Die kritiese leser sou graag een van hierdie teoloë by name genoem wil sien sodat hy die juistheid van Prof. du Preez se aanhaling van hulle gesag kan kontroleer. Soos dit is, woon sommige van die vernaamste teoloë van Europa in England, Frankryk en Holland en in die Skandinawiese lande. Die tiental onder hulle by wie ek navraag gedoen het, weet nie wie Prof. du Preez is nie. Hy moes tog o.a. Prof. Cullmann, Clavier, M. Black, C. K. Barrett, Wendel, J. Bosc, Kurt Aland, Vielhauer, van Unnik en P. van Stempvoort geraadpleeg het. 
Laastens, die werk gaan mank aan wetenskaplike onderskeiding. Die outeur verwar eenheid met eendersheid, gelykwaardigheid met gelykheid, kultuur met Christendom, nasie met Kerk en onderskeidenheid met geskeidenheid.

Die werk dra die ondertitel, Die Hoop van Suid-Afrika. Die hoop in 'n Christelike Suid-Afrika het daarby nie gewen nie.

Prof. A. S. Geyser. 